\title{
凸形表面送波子を用いたリングアレイプローブ
}

\begin{tabular}{|c|c|c|c|c|}
\hline 非会員 & 南 部 & 雅 & 幸 & (奈良先端科学技術大学院大学) \\
\hline 員 & 大 & & 理 & (奈良先端科学技術大学院大学) \\
\hline 非会員 & \pm & 元 & 紀 & ( 奈良先端科学技術大学院大学) \\
\hline 非会員 & 千 原 & 國 & 厷 & (奈良先端科学技術大学院大学) \\
\hline
\end{tabular}

\section{A Ring Array Probe using a Transmitter with a Convex Surface}

Masayuki Nambu, Non-member, Osamu Oshiro, Member, Motonori Doi, Non-member, Kunihiro Chihara, Non-member (Nara Institute of Science and Technology)

This paper describes a newly developed ultrasound ring array probe. The probe has one ceramic ultrasound transducer with a convex surface to transmit ultrasound wave with low directivity and eight polymer hydro-phones surrounding the transducer to receive reflected wave with high sensitivity. Firstly, we measured acoustic pressure distribution of a ceramic transducer and confirmed that the transducer can transmit ultrasound with low directivity. Secondly, we performed experiments to reconstruct a $3 \mathrm{D}$ image of a metal ball using this probe. The experimental results indicated that this probe enable to present the image with higher resolution.

キーワード：超音波，リングアレイプローブ，凸形送波子，前方視，血管内可視化

\section{1 はじめに}

超音波によるイメージングは簡便性，非侵襲性，実時 間性という特徴を有し, 通常の光学的イメージングでは 計測できない身体の内部も可視化できるため，広く臨床 で様々な臓器の診断等に使用されている(1)(2)。また，超 音波センサの小型化に伴い，血管断面という微小領域の 画像化も可能になっている(3).

しかしながら超音波で獲得できる画像は，断層像，す なわち 2 次元画像であり，立体的な情報を獲得するのは， 2 次元断層像を複数獲得して再構成する必要がある. 例 えば心臓の 3 次元イメージングを行うには，心電同期を 用いて 1 心拍ごとに異なる断層像を獲得し，数 10 心拍で の画像を統合して立体像を提示している(4).これは診断 時間の長期化を意味しており，また，加算平均を行って しまうので，ある心拍時にのみ現れる異常を可視化する ことはできない。

近年になり，心䁍の実時間 3 次元イメージングを目指し て，様々な工夫がなされており，時間分解能も $5 \mathrm{frame} / \mathrm{sec}$ 程度まで向上してきた ${ }^{(5)(6)}$ 。しかしながら，心臓等の赛 時間 3 次元イメージングを達成するには時間分解能は不
十分である。

この上うに高時間分解能を有する超音波 3 次元イメー ジングが実現できないのは，超音波イメージングがビー ム走査を基本としており，音速という足咖のためである. 我々は，この音速による時間分解能の拘束を打破する ため，走查を要しないイメージング法(7)-(10)を開発し，血 管内の前方 3 次元立体視に関する研究をを行ってきた。こ の手法は，指向性の低い超音波を，理想的には球面波を 1 回だけ送波し, 反射波を複数の超音波振動子で検出し て映像化を行うものである. この手法は水中で計測範囲 がプローブから $75 \mathrm{~mm}$ の範囲ならば，理論上は $1 \mathrm{sec}$ 間 で, 10,000 回 の画像を獲得することが可能になる.

本手法は超音波振動子を円環状に配置したリングアレ イプローブを用いて行うが，超音波をプローブ中心軸を 囲む広い領域に照射する必要がある，しかしながら，いま まで試作したプローブは指向性が比較的高く，計測領域 がプローブ前面から比較的離れた位置になり，反射信号 の強度および $\mathrm{S} / \mathrm{N} か ゙$ 低く，再構成した画像の画質も低い のが現状であった．打開策としてプローブの振動子を中 心軸を向くように傾けて配置して計測領域をプローブ前 面から近い位置に設定寸ることで, 高解像度の画像を得 
ることに成功した ${ }^{(11)}$. しかし, 計測範囲が狭い範囲に絞 られ，前方の広い領域を可視化することはできなかった。

そこで今回, 送波用の振動子をプローブ中心に配置し, かつ，その表面形状に改良を加えることで指向性の低減 を目論み, 高品質画像の再構成を試みた。本文では, 送 波子, プロープの構造, および実験結果について述べる.

\section{2 凸形表面超音波振動子}

表面が平坦である円状の振動子から送波される連続超 音波は, 図 1 に示すように, 振動子の近傍 (近距離音場 : $\mathrm{y} \leq y_{0}$ ) では収束して進行し, 遠方 (遠距雇音場近 : $\mathrm{y} \geq$ $y_{0}$ ) では中心軸 ( $\mathrm{y}$ 軸) から, ある角度 $\theta$ で拡散しながら 進行する ${ }^{(12)}$.

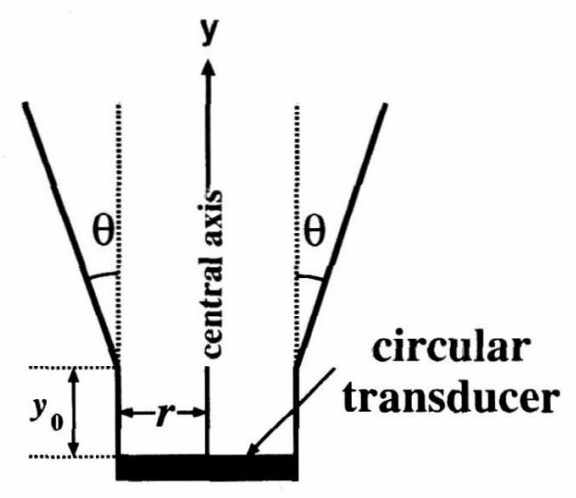

図 1 振動子の指向性

Fig. 1 Directivity of an ultrasound transducer

$\theta$ は, 超音波の減衰を無視した場合, 音圧強度が中心 軸上の值の半分になる角度で，式 (1) ${ }^{(12)}$ で表される.

$$
\sin \theta=0.61 \frac{\lambda}{r}
$$

ここで, $r$ は振動子の半径, $\lambda$ は波長であり, 波長は音 速 $c$ を送波される超音波の周波数 $f$ で割った值 $(\lambda=c /$ f) である. 式 (1) より半径が小さいほど $\theta$ は大きくなる, すなわち, 指向性が低くなる。例えば, 半径が $1.5 \mathrm{~mm}$, 送波中心周波数が $1 \mathrm{MHz}$ である振動子を作製した場合, 水中 $(c=1,500 \mathrm{~m} / \mathrm{sec})$ では $\theta=37.6 \mathrm{deg}$ となる. さら に振動子の半径を小さくすると指向性を低くすることが できるが, 送波する超音波エネルギが小さくなり, 受波 信号強度が小さくなることより $\mathrm{S} / \mathrm{N}$ の低い映像しか得ら れない結果になる。

一方, 薄膜状に加工された超音波振動子は通常図 2-(a) に示すように厚み振動する. このとき、図 2-(b) のように 振動子が厚み方向に一定の曲率で凸な形状を有するなら ば，波は振動面に垂直な方向へ放射されると考えられる。

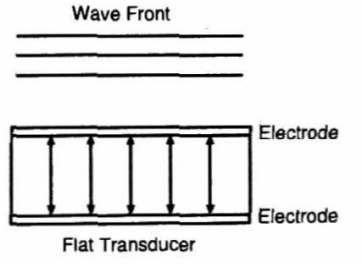

(a)

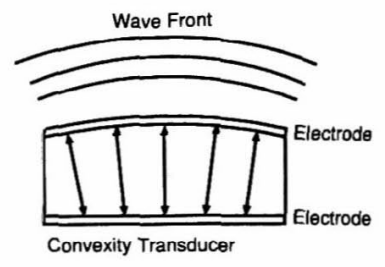

(b)
図 2 振動子の形状による振動方向の違い (a) 平坦形振動子 (b) 凸形振動子

Fig. 2 Difference of vibration direction by shape of ultrasound transducer(a)Flat type(b)Convexity type

そこで, 振動子の表面に曲率を持たせて, 指向性の低 減化を試みた．今回作製した振動子の仕様を表 1 に, フ ローブの概観を図 3(a) に，写真を同図 (b),(c) に示す.

\section{表 1 凸形超音波振動子の仕様}

Table 1 Specification of an ultrasound transducer with a convex surface

\begin{tabular}{cc}
\hline 材質 & セラミクス (PZT) \\
中心周波数 & $1 \mathrm{MHz}$ \\
振動子の半径 & $1.5 \mathrm{~mm}$ \\
曲率 & 10 \\
\hline
\end{tabular}
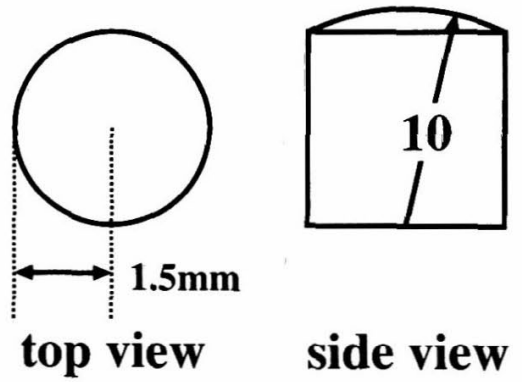

(a)

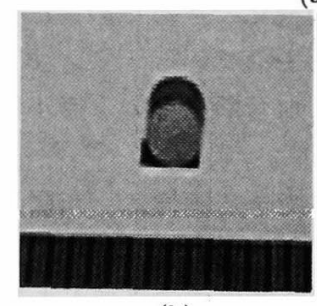

(b)

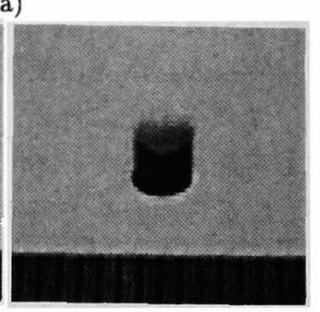

(c)
図 3 凸形超音波振動子 $(R=10)$

(a) 概観 (b) 前方写真 (c) 側方写真

Fig. 3 An ultrasound transducer with a convex surface $(R=10)$ (a)schematic view(b)top view photograph(c)side view photograph 
今回作製した振動子は超音波の送波専用に使用するの で，材料としては機械 - 電気結合係数が高いセラミクス 系とし，チタン酸ジルコン酸鉛 $(\mathrm{PZT})$ を選んだ. 振動子 の大きさは，血管内イメージングを考慮するとできるだ け小さい方が望ましい，また，指向性をできるだけ小さ く設定するため，曲率はできるだけ小さい方が望ましい． しかしながら工作精度により制限を受けるため，今回は 図3(a)に示すように, 半径 $r$ は $1.5 \mathrm{~mm}$, 曲率 $R$ は 10 とした.

今回, この振動子が生成する音圧分布を自動音響強度 測定装置 (NTR Systems 製) を用いて計測した。その結 果を, 図 4 に示す.

黒い丸の位置 $(\mathrm{x}=0, \mathrm{y}=0)$ に設置した振動子から $\mathrm{y}$ 軸方向に超音波を送波し, 音圧分布は $\mathrm{y}$ 軸対称と仮定 して, $\mathrm{y} \geq 0$ の $\mathrm{xy}$ 平面のみで音圧分布の計測を行った. 縦軸は音圧強度 (単位：AU) で, 受波信号の最大 Peakto-Peak 值 $(\mathrm{P}$ - - P ) をプロットした. なお, 比較のため, 表面が平坦である振動子 $(r=1.4 \mathrm{~mm}, f=2.7 \mathrm{MHz})$ が 生成する音圧分布も計測した。

図 4(a) は表面が凸形である振動子が生成する超音波の 音圧分布である. 図より, 原点においた振動子からの距離 に反比例して音圧が低下していることが確認できる．こ の結果は, 原点から全方位に均一に音波が放射されたこ とに起因寸ると考えられ，表面凸形振動子が指向性が低 いことを示している. それに対して図 4(b) は表面が平坦 である振動子が生成する音圧分布である．図より，y 軸 方向では音圧強度はほぼ一定であるが，中心軸から $\mathrm{x}$ 軸 方向に離れるに従い音圧強度は大きく減少しており，表 面平坦振動子が指向性が高いことがわかる.

これらの結果より，振動子の表面を凸形状にすること で，指向性の低い超音波を送波することが可能になるこ とがわかった.

\section{3 超音波リングアレイプローブ}

表面が凸形の振動子は，指向性の低い超音波が送波可 能であることが判明したので,この凸形振動子を送波子 として，超音波リングアレイプローブを試作した：ここ で，超音波をプローブ前面の広い領域に照射するため，送 波子はプローブ中央に設置し，これを取り囲むように8 個の受波子を配置した。受波子は受波感度を優先し，材 料としては高分子のハイドロフォン (東レテクノ製) を用 いた．作製したプローブの仕様を表 2 に，プローブの概 観を図 5(a) に，写真を同図 (b),(c) に示す (送受波子のア センブルは東レテクノが行った).

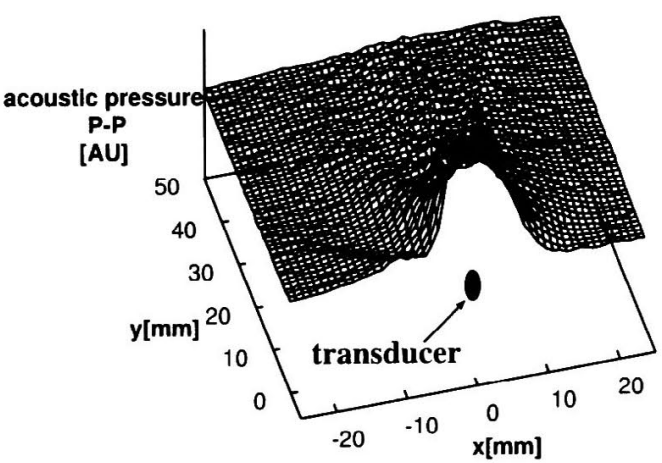

(a)

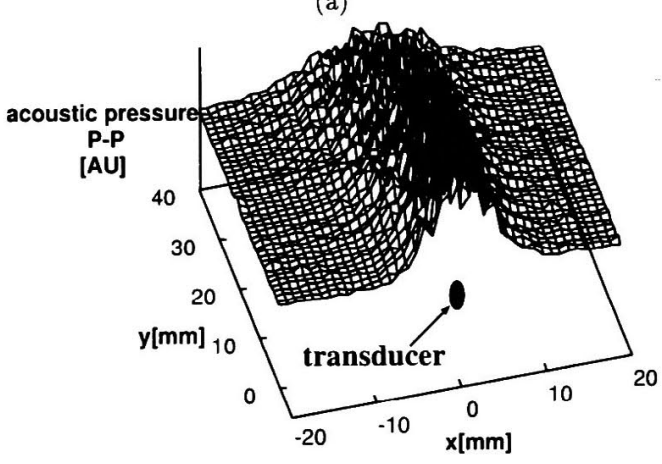

(b)

図 4 振動子が生成する音場分布 (a) 表面凸形振動子 (b) 表面平坦振動子

Fig. 4 Acoustic pressure distribution of an ultrasound transducer (a)with convex surface (b)with flat surface

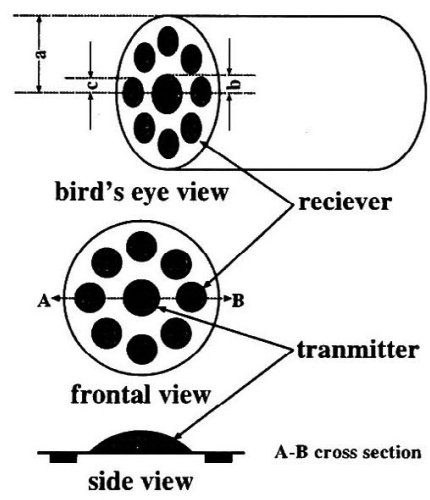

(a)

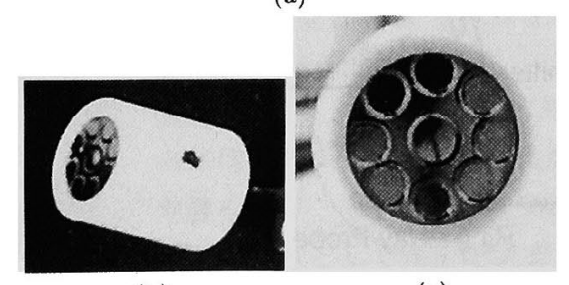

(b)

(c)

図 5 凸形振動子を用いた超音波リングアレイ プローブ (a) 概観 (b) 側方写真 (c) 前方写真

Fig. 5 A ring array probe using a transmitter with a convex surface (a)schematic view(b)side view photograph(c)top view photograph 
表 2 凸形振動子を用いた

超音波リングアレイプローブの仕様

Table 2 Specification of an ultrasound ring array probe using a transducer with convex surface

\begin{tabular}{|c|c|c|}
\hline & 送波子 & 受波子 \\
\hline 材質 & $\mathrm{PZT}$ & 高分子 \\
\hline 中心周波数 & $1 \mathrm{MHz}$ & $1 \mathrm{MHz}$ \\
\hline プローブの半径 & \multicolumn{2}{|c|}{$\mathrm{a}: 5 \mathrm{~mm}$} \\
\hline 振動子の個数 & 1 & 8 \\
\hline 振動子の半径 & $\mathrm{b}: 1.5 \mathrm{~mm}(\mathrm{R}=10)$ & $c: 0.25 \mathrm{~mm}$ \\
\hline
\end{tabular}

このプローブによる画像再構成アルゴリズムは次のと おりである. 図 6 に示すように, プローブ中央を原点と し，ここに配置した凸形超音波振動子から超音波 $s(t)$ を 送信する. $s(t)$ が点 $k$ に存在する反射体 $R_{k}$ によって反 射され，円周上に配置した振動子 $T_{i}$ により受信される. このとき $T_{i}$ で受信される信号 $e_{i, k}(t)$ は

$$
e_{i, k}(t)=a(i, k) r(k) s\left(t-\frac{l_{i, k}}{C}\right)
$$

となる.ここで $a(\mathrm{i}, \mathrm{k})$ は超音波の伝搬に基づく減衰, $r(k)$ は反射係数, $l$ は原点 $\rightarrow R_{k} \rightarrow T_{i}$ の距離, $C$ は音速であ る. すべての $T_{i}$ について $l_{i, k}$ を求めて代入し，すべての $e_{i, k}(t)$ を加算したものを点 $k$ における反射波 (エコー) と する.したがって,

$$
e_{k}(t)=\sum_{i=0}^{N} e_{i, k}(t)
$$

となる.ここで $N$ は振動子の個数である。このメコーを 0 から最大計測時間 $t_{\text {max }}$ まで積分したもの

$$
w_{k}=\int_{0}^{t_{m} a x} e_{k}(t)
$$

を点 $k$ における反射体の存在する確からしさとして, 輝 度に変換し，三次元空間にマッピングすることで三次元 画像を獲得する。

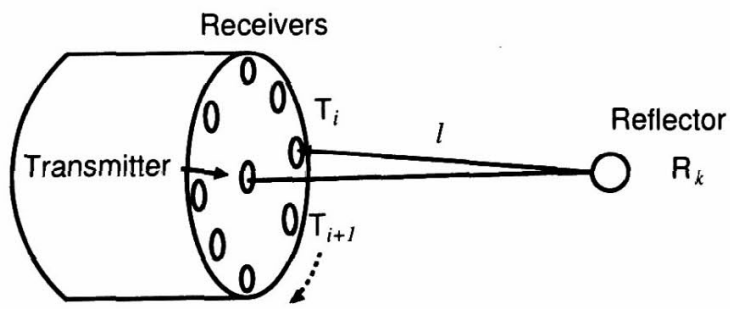

Ring Array Probe

図 6 三次元再構成の原理

Fig. 6 Principle of three-dimensional reconstruction

\section{4 実験と結果}

今回，前方にある立体物の可視化を目的とした 3 次元 可視化の実験を行った. 実験では, 反射波の $\mathrm{S} / \mathrm{N}$ を高く するために，反射物体として金属球 (ステンレス製) を 用いた. 図 7 に示すように, 半径 $2.5 \mathrm{~mm}$ のステンレス 製の球とプローブを $10 \mathrm{~mm}$ 離して水中に設置し，前方立 体視を行った，なお，比較のため，表面が平坦であるプ ローブを用いた 3 次元再構成も行った $(\mathrm{a}=1 \mathrm{~mm}, f=$ $10 \mathrm{MHz})$.

本実験では，新たに開発したプローブによる画質向上 の程度を調べるため, オフラインで実験を行った. 具体的 には, 反射波を一旦ディジタルオシルスコープ (LeCroy 製) に格納し, 計測終了後, 計算機にデータを転送して, 静止画 1 枚のみの再構成を行った.

獲得した前方 3 次元像を, 図 8 に示寸. なお図中の外 枠の大きさは $10 \mathrm{~mm}$ である. また再構成画像の空間分解 能, すなわち再構成 3 次元画像の点を表す立方体の 1 辺 の長さは $0.5 \mathrm{~mm}$ である.

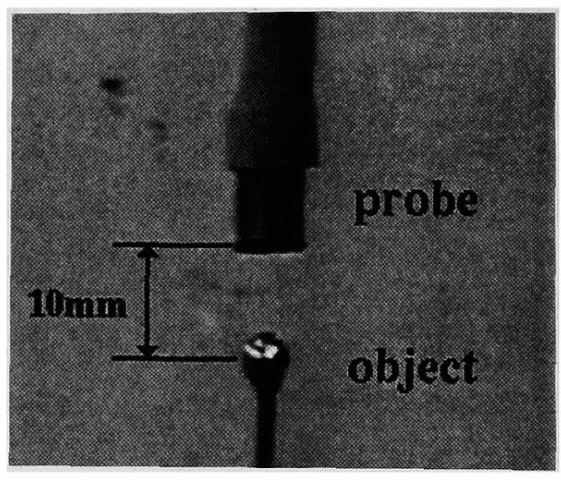

図 7 前方立体視実験

Fig. 7 An experimental arrangement for frontal imaging, where a probe set $10 \mathrm{~mm}$ apart from a measurement object in water.

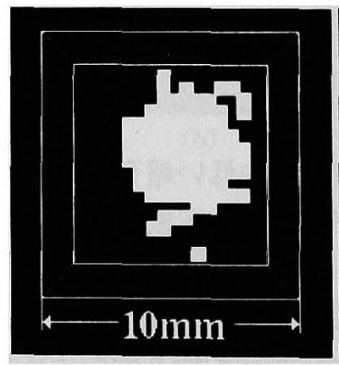

(a)

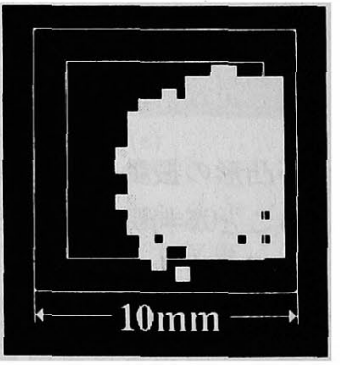

(b)
図 8 前方立体視像

(a) 凸面プローブ (b) 従来プローブ

Fig. 8 Frontal images obtained by (a)a probe with a convex surface transmitter(b)a conventional probe 


\section{5 考察}

図 8 は, 同一の計測対象を再構成した結果である。図 8(a) と図 8(b) を比較すると，(a) が直径 $3.5 \mathrm{~mm}$ の球体に 再構成されたのに対し，(b) は直径 $7.0 \mathrm{~mm}$ と大きく再構 成されている．比較のため用いたプローブは半径 $1 \mathrm{~mm}$, 送波周波数 $10 \mathrm{MHz}$ であり，今回作製したプローブとは 単純には比較できない，しかしながら，使用する超音波 の周波数が高い程, 空間分解能は向上する。また，図 4 に示したように凸形振動子を使用した場合，指向性が低 いため音波のエネルギーは拡散し, 反射波の $\mathrm{S} / \mathrm{N}$ が低下 する. そのため再構成画像中に雑音による虚像が発生し， 再構成画像の画質が著しく低下寸る。これらの不利な条 件にも関わらず，凸形プローブによる再構成画像の方が， より㥶際のサンプルに近い大きさとなった，表面が平坦 で高い指向性を有する振動子を用いて計測を行った場合， 球面波の使用を前提とした本手法の再構成アルゴリズム を用いた場合，計測空間における反射波の分布に著しい 偏倚が存在するため, 再構成画像に虚像が発生する.さ らに振動子の前方に存在する計測対象からの反射波の強 度が大きいため, リンギング（反射波の持続）の影響が 大となり, 同様に虚像が発生する. その結果, 本来プロー ブが有するはずの分解能を実現できないことがある．一 方，本実験の結果が示すように，振動子を凸形に加工し， 低指向性を有する球面波に近い超音波を用いて計測を行 うことにより，高画質の画像を再構成することが可能で ある。

\section{6 おわりに}

今回，表面が凸形状である振動子を送波子として中心 に持つリングアレイプローブを作製した．振動子は表面 が平坦なものと比べると指向性が低下しておう，本研究 の主旨に見合ったものが作製できた. またこのプローブ で前方 3 次元計測を行ったところ, 従来よりも高解像度 の 3 次元画像を再構成することができた．中央の振動子 をさらに小型化することで，血管内前方イメージングに 用いることができると考えられる.

なお, 本研究の 1 部は, 日本学術振興会 未来開拓学術 研究推進事業 (JSPS-RFTF97100402:超音波診断と治療 の革新的基礎技術の開発) の補助をを受けて行ったもの である.

(平成 11 年 6 月 23 日受付, 平成 12 年 10 月 10 日再受 付)

\section{文献}

（1）和賀井敏夫, 松尾裕英: ”超音波医学”, 永井書店 (1985)

電学論 E, 121 巻 3 号, 平成 13 年
（2）渡辺 泱, 大江 宏: "腎と泌尿器科超音波”, 南江 堂 (1985)

(3) 大城 理, Md. Salimuzzaman, 畺溪 歩, 千原國 宏, 浅生雅人: "マイクロモータによる超音波イメー ジング", 電気学会論文誌 $\mathrm{E}$ センサ・マイクロマシン 部門 118, 193-197 (1998)

(4) O. Oshiro, A. Matani, K. Chihara, T. Mikami and A. Kitabatake : "Three Dimensional Echocardiography with the Reconstructed B-mode Image", Japanese Journal of Applied Physics 36, 3221-3225 (1997)

(5) J. Lu:"2D and 3D high Frame Rate Imaging with Limited Duffration Beams", IEEE Transactions on Ultrasonics, Ferroelectrics, and Frequency Control,838-839 (1997)

（6）望月 剛, 赤羽睦弘, 河西千広, 尾本良三, 松村 誠 : ”超音波を用いた実時間 3 次元表示装置の開発”, 日本音響学会 1999 年春期研究発表会 講演論文集, 2-5-17 1131-1132 (1999)

（7）大城 理, 東條博史, 千原國宏: ”超音波アレイプ ローブを用いた 3 次元可視化システム”, システム制 御情報学会論文誌 39, 344-349 (1995)

(8) 西尾真博, 藤田匡佑, 芳賀洋一, 江刺正喜: "血管 内前方視超音波イメージャのための集積化プローブ の試作”，第 39 回日本 ME 学会大会論文集, 107 (2000)

(9) W.R.Lewis and H. Lee: "High-Resolution Image Reconstruction Techniques for Circular-Aperture Array Imaging Systems", Acoustical Imaging, 3743,(1996)

（10）田村安孝: "計算機処理による超音波イメージング", Medical Imaging Technology, 17-1, 26-34 (1999)

(11) A. Matani, M. Nambu, A. Kondo, O. Oshiro and K. Chihara : "A Method of 3D Measurement with High Resolution Using Ultrasound Spherical Waves", Japanese Journal of Applied Physics 36, 3255-3259 (1997)

(12) K. K. Shung, M. B. Smith and B. Tsui : "Principles of medical imaging", Academic Press (1992)

南 部 雅 幸 (非会員) 1967 年 4 月 21 日生まれ。 1991 年東京理科大学卒業. 1991 年島津 製作所入社. 1995 年奈良先端科学技術 大学院大学入学. 1997 年同大学博士前 期課程修了. 1997 年同大学博士後期課 程進学. 主として現在超音波計測, 3 次 元可視化の研究に従事.

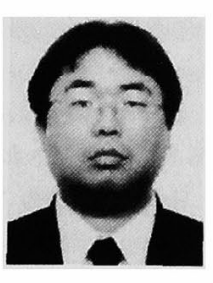




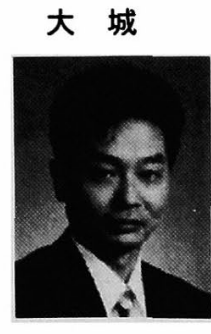

理 (正員) 1962 年 7 月 23 日生. 1990 年大阪大学大学院博士課程修了. 同年住 友金属工業人社. 1993 年奈良先端科学技 術大学院大学情報科学研究科助手. 1994 年同大学先端科学技術研究調查セン夕助 教授．主として超音波計測，医用画像処 理, 3 次元可視化の研究に従事. 工博.

土居 元 紀 (非会員) 1971 年 3 月 8 日生まれ.

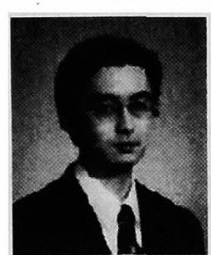
1993 年大阪大学基礎工学部卒業. 1998 年奈良先端科学技術大学院大学博士後期 課程修了. 同年同大学情報科学研究科助 手，主として画像認識，医用画像解析， 超音波センサの研究に従事. 工博.

$千$ 原 國 宏 (非会員) 1945 年 5 月 14 日生まれ.

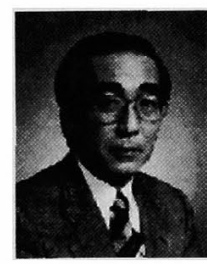
1973 年大阪大学大学院博士課程修了. 同 年同大学基礎工学部助手. 1983 年同大学 基礎工学部助教授. 1992 年奈良先端科学 技術大学院大学情報科学研究科教授. 主 として医用超音波計測，生体内可視化の 研究に従事. 工博. 